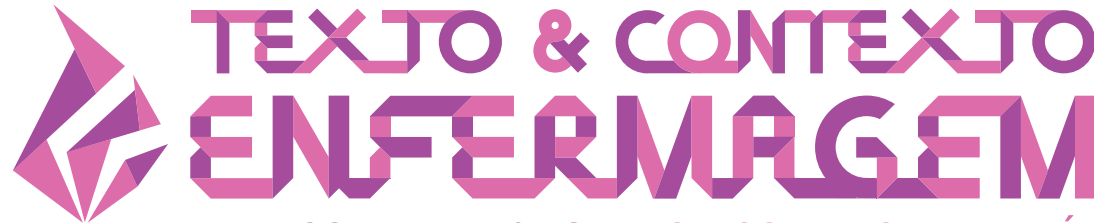

TEXT \& CONTEXT NURSING TEXTO \& CONTEXTO ENFERMERÍA

\section{ETHNONURSING: CULTURAL CARE IN A MAPUCHE COMMUNITY IN PUERTO AGUIRRE, AYSÉN, CHILE}

\author{
Marisa Angélica Mansilla Ojeda ${ }^{1}$ (i) \\ Ivonete Teresinha Schulter Buss Heidemann ${ }^{2}$ (D) \\ Sergio Eduardo Contreras Villa ${ }^{3}$
}

${ }^{1}$ Universidad de Magallanes. Punta Arenas, Magallanes, Chile. 2Universidade Federal de Santa Catarina, Programa de Pós-graduação em Enfermagem. Florianópolis, Santa Catarina, Brasil. 3Universidad de Magallanes. Coyhaique, Aysén, Chile.

\begin{abstract}
Objectives: to understand the beliefs, expressions, and practices of generic care used by the Mapuche community in Puerto Aguirre and acknowledge the professional care offered to promote health.

Method: a qualitative research based on ethnonursing carried out during seven trips to Puerto Aguirre between July 2018 and January 2019. A total of seven key informants and seven general informants were interviewed. Information was collected through observations, field notes, conversations, and interviews.

Results: the scientific property of ethnonursing was verified. Three themes that structure the cultural care practices in the studied community emerged: Mapuche identity as the main value to preserve cultural care; The essesntial presence of women to carry out meaningful experiences and care practices among the Mapuche; and Mapuche value and use of cultural and professional care practices to promote health.

Conclusion: the research recognizes the full validity of the Cultural Care Theory. Nursing and, in general, the different health professions tend to become popular, and professional knowledge is complemented, thus learning and improving cultural care in the community.
\end{abstract}

DESCRIPTORS: Transcultural nursing. Care. Ethnic groups. Anthropology, cultural. Nursing research. 


\section{ETNOENFERMERÍA: CUIDADOS CULTURALES EN UNA COMUNIDAD MAPUCHE EN PUERTO AGUIRRE, REGIÓN DE AYSÉN-CHILE}

\section{RESUMEN}

Objetivos: comprender las creencias, expresiones y prácticas de cuidados genéricos utilizados por la comunidad mapuche en Puerto Aguirre y reconocer la atención profesional ofrecida a la Promoción de la Salud.

Método: investigación cualitativa basada en la Etnoenfermería, llevada a cabo durante siete viajes a Puerto Aguirre realizado entre julio de 2018 y enero de 2019. Se entrevistó a un total de siete informantes claves y siete informantes generales. Las informaciones fueron recopiladas por intermedio de observaciones, notas de campo, conversaciones y entrevistas.

Resultados: se constató la propiedad científica de la Etnoenfermería, identificándose tres temas que estructuran las prácticas de cuidado cultural en la comunidad estudiada: La identidad mapuche como principal valor para preservar el cuidado cultural; La presencia de mujeres es esencial para la realización de experiencias y prácticas de atención significativas entre los mapuches; y Los mapuches valoran y utilizan las prácticas de cuidado cultural y profesionales para promover la salud.

Conclusión: la investigación reconoce la plena vigencia de la Teoría del Cuidado Cultural, pues la enfermería $y$, en general, las diferentes profesiones de la salud, tienden a popularizarse y el conocimiento profesional se complementa, aprendiéndose y mejorando así el cuidado cultural en la comunidad.

DESCRIPTORES: Enfermería transcultural. Cuidados. Etnia. Etnografía. Investigación en enfermería.

\section{ETNOENFERMAGEM: CUIDADOS CULTURAIS EM UMA COMUNIDADE MAPUCHE EM PUERTO AGUIRRE, AYSÉN, CHILE}

\section{RESUMO}

Objetivos: compreender as crenças, expressões e práticas genéricas de cuidado utilizadas pela comunidade mapuche em Puerto Aguirre e reconhecer o cuidado profissional oferecido à promoção da saúde.

Método: pesquisa qualitativa baseada na etnoenfermagem, realizada durante sete viagens a Puerto Aguirre, realizadas entre julho de 2018 e janeiro de 2019. Foram entrevistados sete informantes-chave e sete informantes gerais. As informações foram compiladas por meio de observações, anotações de campo, conversas e entrevistas.

Resultados: confirmou-se a propriedade científica da etnoenfermagem, identificando três temas que estruturam as práticas de cuidado cultural na comunidade estudada: A identidade mapuche como principal valor para preservar o cuidado cultural; A presença de mulheres é essencial para realizar experiências e práticas de cuidado significativas entre os mapuches; e Os mapuches valorizam e usam práticas de cuidado cultural e profissional para promover a saúde.

Conclusão: a pesquisa reconhece a validade plena da Teoria do Cuidado Cultural, uma vez que a enfermagem e, em geral, as diferentes profissões da saúde, tendem a se popularizar e o conhecimento profissional é complementado, aprendendo e aprimorando o cuidado cultural na comunidade.

DESCRITORES: Enfermagem transcultural. Cuidado. Grupos étnicos. Antropologia cultural. Pesquisa em enfermagem. 


\section{INTRODUCTION}

People as complex entities cannot be Sept arated from their cultural origin, social structure, world conception, life trajectory and context of their environment. Hence there is no doubt that cultural elements such as religious worldviews, myths, taboos, uses and customs affect health and disease. Definition of health, interpretation of symptoms, care and treatment to promote and recover health are culturally defined.

Madeleine Leininger ${ }^{1}$ provides a holistic approach to care knowledge, articulating the fundamental bases of nursing, under the perspective of social sciences, and particularly anthropology. Leininger understood that it was essential to generate a culturally-competent nursing, supported by a robust theoretical model, which allowed nurses to expand their knowledge and understanding of different cultures. ${ }^{2}$ This is how ethnography will adapt to the study of the specific object of nursing, human care. Her research with New Guinea's Gadsup language would be the first time that a study inspired by a new theory would have been carried out and, at the same time, based on a new methodological approach, etnonursing. ${ }^{3}$

A prolonged research, systhemetization and dissemination effort allowed Leininger show the relevance of cultural care, which individuals and families provide from their particular worldview, cultural patterns and practices. Studying and recognizing such care will be a fundamental help for nurses to deliver consistent care to individuals, families and communities. The theoretical construction correlates directly with the quality of care provided by nursing professionals, improving user well-being.

Nursing must identify, in those who must protect, all practices and values that promote wellbeing and adequate living conditions to preserve health. In this regard, if the belief or practice is beneficial, or if it does not harm patients' lives, it must be preserved and even encouraged.

This study seeks to explore in more depth the central characteristics of ethnonursing. This refers to a qualitative nursing research method focused on naturalistic, open, and broadly inductive (emic) modes of discovery. Such method allows documenting, describing, explaining, and interpreting worldviews, meanings, symbols, and life experiences of informants, as they have to do with actual and potential nursing care phenomena. ${ }^{4}$

Likewise, this research seeks to understand the beliefs, expressions, and practices of generic care used by the Mapuche community in Puerto Aguirre and to acknowledge the professional care offered for health promotion.

\section{METHOD}

This investigation is based on the qualitative paradigm as a descriptive, inductive, exploratory, and reflective study.

Ethnonursing was used, a qualitative research method developed by Leininger for nursing, consistent with the Cultural Care Theory. This is a rigorous, systhemetic and, in-depth method to study multiple factors of culture and care in the environment of people and to focus on the interrelation between health care and culture. ${ }^{2}$

This study is classified, according to Leininger's own taxonomy, as a mini ethnonursing study. ${ }^{5}$ It has approximately six to eight key informants who are interviewed and observed over a period of six to eight months.

Ethnonursing allowed the researcher to work in an open and flexible way. Ethnonursing allowed her to discover unknown aspects of the behaviors, knowledge, and assessments of the cultural care of the Mapuche community in local and natural environments of Puerto Aguirre, Las Huichas Island, Aysén region, Chile. 
Isla Huichas has three locations: Puerto Aguirre, Estero Copa, and Caleta Andrade. They are located in the province and region of Aysén. It can only be accessed by sea or air, the former prevailing, given the high cost of air transportation. In this case, the island is three hours by speedboat from Puerto Chacabuco, the nearest continental port. ${ }^{6}$

Puerto Aguirre comprises 541 inhabitants (288 men and 253 women). Half of the population identifies themselves as belonging to an ethnic group and $91 \%$ of them consider themselves Mapuche. Fishing activity predominates, and Mapuche is considered a socially-vulnerable community, with $87 \%$ of the population living in poverty. ${ }^{\text {? }}$

The researcher entered the field of study through the manager of the Health Program for Indigenous Peoples, who is also a representative of the Mapuche community. He was born 40 years ago in the community of Puerto Aguirre, where he lives today. Three visits were scheduled on the first trip (July 2018), all carried out in the company of the Intercultural Delegate. On his first trip, he introduced her to several of his sisters, brothers-in-law and his own mother as well as different people from the island's Mapuche community. This group of people constitutes an important part of who were the main informants.

Selecting the first three key informants was carried out through the information provided by the Intercultural Delegate, intentionally. The other key informants were chosen by snowball sampling. This allowed that key informants were always selected through the presentation or reference of a member recognized by the Mapuche Community.

All those living in Puerto Aguirre, who identify or recognize themselves as Mapuche, were selected. General informants were selected according to the relevant roles that each one plays within the community of Puerto Aguirre, a situation that raised the researcher's interest in learning about their stories. Sample was made up of seven key informants and seven general informants.

In coordination with the person in charge of the Special Health Program for Indigenous Peoples (PESPI - Programa Especial de Salud para Pueblos Indígenas), the researcher stayed on Isla Las Huichas on numerous occasions between July 2018 and January 2019. This allowed for fluid communication and close contact with the community to carry out and investigation. The first and penultimate time, she went alone, and on other occasions, she went with a sociologist who worked as a methodological assistant.

She conducted interviews with key informants applying the ethnonursing method. She applied a semi-structured interview guideline aimed at opening a conversation about beliefs and practices related to care, which presented issues regarding sociodemographic and health history, then about all care and cultural practices used by them.

Firstly, she introduced herself as a professor and mentioned that she was studying the way people are cared for on the island. If the possible informants showed interest to participate, they were asked to read and sign the Informed Consent Form. In some cases, it was necessary to explain the consent inform to the informant.

She used two different interview guidelines, one for key informants, and another for general informants (guides), according to the Rising Sun Model.

The researcher followed the observation phases typical of ethnonursing. ${ }^{4}$

Phase I: Broad view of the research topic, without fully participating in activities or events.

Phase II: Oriented-observation according to the information gathered through incipient contact with key and general informants

Phase III: Active participation of the researcher in activities.

Phase IV: Distance and assessment of the researcher on the impact of her presence on participants.

Field notes were used, taken during and after the interviews, those observed at home and in the community; and afterwards, the recorded interviews were reviewed. 
Four of the five models proposed by Leininger were used. ${ }^{5}$ The most used was the Rising Sun Model, which helped to systhemetize the information gathered from the interviews.

Analysis of the information was carried out according to the phases of ethnonursing: the interviews were transcribed manually and the texts were analyzed after the four phases of analysis of the qualitative information of ethnonursing. ${ }^{8}$ All information collected in the interviews with the main informants and general informants, as well as the observations and other verifiable history related to the Isla Huichas community were considered. This support facilitated information systematization, assigning the codes associated with the Care Theory's categories and domains.

From an exhaustive search and collection of data from key and general informants, the researcher reached information saturation when it became evident that the additional information collected from informants did not add relevant findings to the research domain.

Concerning ethical requirement, the current institutional regulations of the Scientific Committee of the University of Magallanes and the Board of the Health Service of Aysén were complied with. This meant obtaining the Certificate of Approval from the Scientific Ethics Committee by the Vice-Dean of Research and Graduate Studies at the University of Magallanes, which was granted on May 31, 2018; and by the Scientific Ethics Committee of the Aysén Health Service, granted on 10 January 2018.

\section{RESULTS}

\section{Phase 1: Collection, description, and documentation of raw data}

The researcher collected, described and recorded information related to the objective, research domain and study questions. The interviews' raw records were contemplated and the observations were subsequently recorded in the field diary.

There were seven key informants, people self-identified as of indigenous origin and members of a Mapuche community group. Of these, seven were women, of all ages, born and raised there.

The general informants interviewed were seven members of different institutions and public services present on the island. Moreover, conversations were held with personnel from the Porto Captaincy, Carabineros, Civil Registry, Postal Service and the priest, who was among the Catholic community on the Island, on more specific topics that did not properly constitute the interviews.

\section{Phase 2: Presentation of categories}

All data were reviewed and coded according to the research domain and research questions. The emic and ethical descriptors were studied in context for similarities and differences.

A first systematization of information was prepared according to the Rising Sun Model as a first step to discover the emerging categories in the research and to better understanding the Mapuche community's life (Chart 1). ${ }^{5}$ The Mapuche's worldview or life context was explored through meanings associated with the Rising Sun Model, and included technological, religious and spiritual, family and social, family and social, political and legal, economic and educational factors. 
Chart 1 - Systhemetization of information based on the social structure and holistic health of the Mapuche community. Puerto Aguirre-Chile, 2019

\begin{tabular}{|c|c|}
\hline \multicolumn{2}{|c|}{ Social structure and holistic health of the Mapuche community } \\
\hline \multicolumn{2}{|r|}{ Worldview } \\
\hline \multicolumn{2}{|c|}{$\begin{array}{l}\text { Most identify themselves as Mapuche and this was a surprise to me because I thought there was a great } \\
\text { rejection, because we are a community that has no identity, copying models (G7). } \\
\text { We already do more for the natural. I, on the part of (my) family, come more naturally. The dissemination } \\
\text { of my mother's knowledge, which comes from Chiloé, comes more with the medicinal herb (C7). } \\
\text { Chonos was a very advanced city (G7). }\end{array}$} \\
\hline Technological Factors & $\begin{array}{l}\text { I believe that the arrival of } 24 / 7 \text { light and television antennas has been the } \\
\text { most harmful for the population (G2). } \\
\text { Something very special happens: although we are so close and far from } \\
\text { everything that life has today, we are so close to technology, to connectivity, } \\
\text { but at the same time so far, because we are on an island (G3). }\end{array}$ \\
\hline $\begin{array}{c}\text { Religious or } \\
\text { philosophical factors }\end{array}$ & $\begin{array}{l}\text { My God gave me this gift to help others (C6). } \\
\text { There is only one Being who has all things. He owns life. Whenever he } \\
\text { wants, he gives it and takes it (G1). }\end{array}$ \\
\hline Family and social factors & $\begin{array}{l}\text { Thank God, although there are differences, we are always together, family } \\
\text { support is essential (C2). } \\
\text { If families do not care about their daughters or relatives, problems arise. } \\
\text { Having healthy children who can work support the family, that is enough } \\
\text { (C3). } \\
\text { Here the whole family goes fishing, they get stronger as a family, as an } \\
\text { institution (G4). }\end{array}$ \\
\hline Political and legal factors & $\begin{array}{l}\text { The association of residents is responsible for working with communities. } \\
\text { There are three neighborhood councils, but this depends on the control } \\
\text { exercised by the municipality. Suddenly, there are leaders who mark you, } \\
\text { even if they want to do things that stop you. (It is) a negative counterpart } \\
\text { (G7). } \\
\text { This country is the third country in the world that has (more) islands and } \\
\text { does not have adequate legislation (G7). } \\
\text { Therefore, the rural health policy for this region is different from the rest of } \\
\text { the country. You need to generate resolution locations of what is normally } \\
\text { expected from a center in this case (G5). }\end{array}$ \\
\hline Educational factors & $\begin{array}{l}\text { Young people rarely return with a professional title (C2). } \\
\text { One hundred percent of children or people who go out looking for studies or } \\
\text { something usually don't come back for the same reason. Because they feel } \\
\text { that they cannot step up their standard of living here (G3). }\end{array}$ \\
\hline Economic factors & $\begin{array}{l}\text { Most of them are artisanal fishermen. Divers became artisanal fishmongers. } \\
\text { Many people left; here the population reaches more or less 1,500 inhabitants } \\
\text { among the three communities (G7). } \\
\text { There are many marine products, but the red tide does not allow harvesting. } \\
\text { There are protected animals, such as the sea lion, the otter. They cannot be } \\
\text { hunted (C1). }\end{array}$ \\
\hline
\end{tabular}


Chart 1 - Cont.

\begin{tabular}{|c|c|c|}
\hline \multicolumn{3}{|c|}{ Holistic Health System } \\
\hline Cultural systems & Nursing care - health promotion & Professional systems \\
\hline $\begin{array}{l}\text { Our family, in one way or } \\
\text { another, practices ancient } \\
\text { medicine, because we } \\
\text { discovered it (G7). } \\
\text { I'll get some hooks from - } \\
\text { there's a wood that says } \\
\text { the luma, l'm going to } \\
\text { make them boil and I do it } \\
\text { with burnt sugar. I take it } \\
\text { and it is a sacred medicine } \\
\text { (G1). } \\
\text { They use sea lion oil, } \\
\text { hunting is prohibited and; } \\
\text { therefore, is no longer } \\
\text { used. Sea lion hunting can } \\
\text { be prohibited, because it } \\
\text { always happens (C5). }\end{array}$ & $\begin{array}{c}\text { As a former paramedic, I see the } \\
\text { potential for interculturality. From the } \\
\text { beginning, we are going to do the plant } \\
\text { workshop, there is someone who creates } \\
\text { soap oil, etc. (G4). } \\
\text { Totally willing to work with Mapuche } \\
\text { medicine, it would be a contribution. If } \\
\text { you can take medicine in your garden, it } \\
\text { is accessible and you don't need to go to } \\
\text { a pharmacy (G5). } \\
\text { "Overweight and obesity occur in all age } \\
\text { groups. In children of all age groups. } \\
\text { The relationship that La Posta has } \\
\text { with educational institutions is through } \\
\text { vaccines/control. Everything goes to La } \\
\text { Posta. They are done in days. Childhood } \\
\text { and adolescence health control is made } \\
\text { by appointment, and with kindergarten, } \\
\text { informative lectures are coordinated } \\
\text { throughout the year. (These are) certain } \\
\text { activities that are carried out (G4). }\end{array}$ & $\begin{array}{l}\text { Most people who go to } \\
\text { consultations are women, } \\
\text { children and older adults, men } \\
\text { are not. The men who go to } \\
\text { consultation are those on board. } \\
\text { In fact, the men of the island do } \\
\text { not go to consultation, they do } \\
\text { not come much to La Posta (G4). } \\
\text { Well, for example, here in La } \\
\text { Posta, since I listen to reason, I } \\
\text { spoke to him about } 45 \text { years ago, } \\
\text { because even a } 15 \text {-year-old boy } \\
\text { realizes several things. La Posta, } \\
\text { in a way, has been strengthening } \\
\text { in the sense that today we can } \\
\text { count on doctors (G1). }\end{array}$ \\
\hline
\end{tabular}

With the first order presented in Chart 1 and according to the Sun Rising Model, ${ }^{5}$ the researcher was able to interpret and recognize three themes, which were identified through the statements. The themes are: Mapuche identity as the main value to preserve cultural care; The essential presence of women to carry out meaningful care experiences and practices among the Mapuche; Mapuche value and use of cultural and professional care practices to promote health.

\section{Phase 3: Presentation of patterns}

In phase 3, data were reviewed to discover saturation of ideas and recurring patterns of similar or different meanings. The data were examined to show patterns with respect to meanings in context along with greater credibility and confirmation of findings. From the categories supported by the informants' responses, the following patterns emerged:

1. Importance of acknowledgment as a Mapuche ethnic group to continue with cultural care. The categories that support this pattern are: Mapuche identity, care, meanings and expressions of care, women's role.

2. Women's health as the main family caregiver and in charge of providing health and illness care. The categories that support this pattern are: family support, Mapuche identity, care, meaning and expressions of care.

3. Family as a form of care and protection to the community, the categories that underlie this pattern are: women's role, family support, meaningful care and expressions of care.

4. Oriented professional care to recognize interculturality to promote health and well-being. The categories that support this pattern are: care, meanings and expressions, professional health care, no care. 
5. Popular care and use of cultural practices to promote health and well-being. The categories that support this pattern are: family support, care, meanings and expressions of care, Mapuche Identity, women's role.

\section{Phase 4: Presentation of themes}

Chart 2 presents a synthesis of the three themes resulting from the research, detailing the patterns, categories and textual citations associated with each theme.

Chart 2 - Theme synthesis. Puerto Aguirre-Chile, 2019

\begin{tabular}{|c|c|}
\hline \multicolumn{2}{|c|}{ Theme 1 - Mapuche identity as the main value to preserve cultural care } \\
\hline \multirow{3}{*}{$\begin{array}{l}\text { Importance of } \\
\text { acknowledgment as an ethnic } \\
\text { group (Mapuche) to continue } \\
\text { with cultural care. (Mapuche } \\
\text { identity, care, meanings and } \\
\text { expressions of care, women's } \\
\text { role). }\end{array}$} & $\begin{array}{l}\text { Most of the population identifies as Mapuche, and for me that has been a } \\
\text { surprise because I thought there was a great rejection, because we are a } \\
\text { community that has no identity, copying models (G7). }\end{array}$ \\
\hline & $\begin{array}{l}\text { This island is inhabited by the Chilote; they went down the channels } \\
\text { looking for work and they brought the Mapuche culture all the culture and } \\
\text { knowledge of herbs. That is innate and typical of the Mapuche. That is } \\
\text { constant, it is part of life. I see that reflected here (G4). }\end{array}$ \\
\hline & $\begin{array}{l}\text { Our family, in one way or another, practices ancient medicine, because } \\
\text { we discovered it (G7). }\end{array}$ \\
\hline \multicolumn{2}{|c|}{$\begin{array}{l}\text { Theme } 2 \text { - The essential presence of women to carry out meaningful } \\
\text { care experiences and practices among the Mapuche }\end{array}$} \\
\hline \multirow{3}{*}{$\begin{array}{l}\text { Women's role as the } \\
\text { main family caregiver and } \\
\text { responsible for providing } \\
\text { health and illness care } \\
\text { (family support, Mapuche } \\
\text { identity, care, meaning and } \\
\text { expressions of care). }\end{array}$} & $\begin{array}{l}\text { There is the presence of women, the maternal, labor, cultural and } \\
\text { religious role, empowered women. Here, women are very strong; they } \\
\text { are super empowered, they do the same as men. Women have a role } \\
\text { in all aspects, economic, social. Men are more shy, but more violent. } \\
\text { (They are) inserted in the way of living (in which) women are heads of } \\
\text { household (G5). }\end{array}$ \\
\hline & $\begin{array}{l}\text { One of the ingredients has herbs, grass and urine. When you are a child, } \\
\text { you have no fever and are healthy. I learned it myself, I don't know if God } \\
\text { gave me to help people, it's not so much to charge } 2 \text { or } 3 \text { thousand pesos } \\
\text { per person, because they spend more when they go to Coyhaique (C6). }\end{array}$ \\
\hline & $\begin{array}{l}\text { Most people who go to consultations are women, children and older } \\
\text { adults, men are not. The men who go to consultation are those on board. } \\
\text { In fact, the men of the island do not go to consultation, they do not come } \\
\text { much to La Posta (G4). }\end{array}$ \\
\hline \multicolumn{2}{|c|}{ Theme 3 - Mapuche value and use of cultural and professional care practices to promote health } \\
\hline \multirow{4}{*}{$\begin{array}{l}\text { Popular care and use of } \\
\text { cultural practices to promote } \\
\text { health and well-being. (family } \\
\text { support, care, meanings and } \\
\text { expressions of care, Mapuche } \\
\text { identity, women's role). } \\
\text { Professional Care is oriented } \\
\text { to recognize Interculturality, } \\
\text { to promote health and well- } \\
\text { being. (care, meanings and } \\
\text { expressions, professional } \\
\text { health care, no care). }\end{array}$} & $\begin{array}{l}\text { They use sea lion oil, hunting is prohibited and; therefore, is no longer } \\
\text { used. Sea lion hunting can be prohibited, because it always happens } \\
\text { (C5). }\end{array}$ \\
\hline & $\begin{array}{l}\text { Well, for example, here in La Posta, since I listen to reason, I spoke to } \\
\text { him about } 45 \text { years ago, because even a 15-year-old boy realizes several } \\
\text { things. La Posta, in a way, has been strengthening in the sense that today } \\
\text { we can count on doctors (G1). }\end{array}$ \\
\hline & $\begin{array}{l}\text { I try to mention it as complementary medicine, since they are compatible. } \\
\text { Today there is a revolution in the way of living, returning to the most } \\
\text { natural. A deal was made anyway. Some went too far. I think we need to } \\
\text { complement it (G5). }\end{array}$ \\
\hline & $\begin{array}{l}\text { As a former paramedic, I see the potential for interculturality. From the } \\
\text { beginning, we are going to do the plant workshop, there is someone who } \\
\text { creates soap oil, etc. (G4). }\end{array}$ \\
\hline
\end{tabular}




\section{DISCUSSION}

This study being the first to recognize the cultural care prevalent in the Mapuche community of Puerto Aguirre, Chile, the researcher focused on finding sources in Spanish and English. She selected, for the purposes of the discussion, references that could document consistency with the thematic findings of this study. To examine these sources, they will be presented in chronological order of appearance in the discussion of each topic.

As the main value to preserve cultural care, it coincides with the result of other investigations carried out in several indigenous communities. A study among Potawatomi in rural Michigan ${ }^{9}$ identified, as one of the themes resulting from this research, the significant influence of Native American spirituality on health and well-being.

A study carried out in Shuar communities, ${ }^{10}$ in the Zamora-Chinchipe province, ${ }^{8}$ to find out their health-seeking preferences, in particular, economically independent older people, took pride in their traditional Shuar health-seeking knowledge and practices, ignored by the younger generation.

An ethnonursing study inspired by the Cultural Care Theory, carried out among 15 mothers from Vila Nova Maringá, ${ }^{11}$ pointed out that the female figure, especially the maternal one, stands out for disseminating knowledge, which occurs for generations vertically and orally. According to the research nurse, this finding coincides with similar results from other previous research. ${ }^{11}$

Another study, conducted among Russian and Vietnamese refugees in the United States, yielded a similar result by defining theme 3 of the research as "health care decisión-making". Refugees of both nationalities sought health services that had some family attributes, that were reliable, economically accessible, and that allowed the presence of valuable socio-cultural supports for their people. ${ }^{12}$

Tom-Orme noted similar conclusions in his analytical synthesis of cross-cultural health care and nursing among the native peoples of the United States. ${ }^{12}$ Traditional indigenous care practices are used in parallel with access to Western allopathic medicine. Indigenous people are currently unlikely to resort exclusively to traditional practices. ${ }^{13}$

A study on consistent care at the end of life in the Appalachian rural population identified a pattern of seeking to integrate cultural or popular care into their care at the end of life and the issue of integrating cultural and professional care to obtain consistent care at the end of life. ${ }^{14}$

It is pertinent to take into account the results of an investigation carried out from June 2014 to February 2015 among users, health agents, intercultural models and health providers, at two health facilities in the province of Arauco, in Chile. It was found among providers the difficulty of implementing the "ideal" underlying the concept of intercultural health; therefore, it would be possible to carry out only certain actions that allow configuring care with greater relevance..$^{15}$

An investigation conducted in late 2012 and 2013 among indigenous families in the State of Chihuahua (Mexico) explored the perceptions of nurses and indigenous people regarding community care.$^{16}$ Although the research focus was not ethnonursing, but the grounded theory, it appears that its conclusions are very close to the themes evidenced in the other studies examined here. There is an incompatibility between using the Cultural Care Theory terms, professional cultural care and culture. On the one hand, the biomedical model predominates in nursing practices; and, on the other hand, distrust of health workers often prevents indigenous people from seeking the care they need in the health system. ${ }^{16}$ 
The same investigation gave rise to another manuscript, in which dissociation of nursing professionals with the indigenous population cultural care was evidenced. This fact gave professional care and conventional medicine the character of a cultural imposition, causing passive behaviors, resistance, non-adherence to treatments, which affect the quality of care provided. Nursing professionals assume a relationship of superiority and distance in relation to indigenous families. Families experience distrust and feelings of doubt about a health system insensitive to treatment, little or no way of being. ${ }^{17}$

Donahue's qualitative research on suicide among the Navajo people, in the Navajo Reserve in Arizona and New Mexico, found that there are two main types of health professionals in the reserve: healers and traditional doctors. ${ }^{18}$ Although in the past there was no communication or mutual acceptance of their practices, today it seems that both types of care are related. Healers and doctors work together in hospitals, it is not uncommon to see them converse in the hospital. Doctors may allow patients to temporarily leave the hospital to participate in a healing ceremony outside the hospital. However, there are Navajo who do not feel embraced by healthcare professionals, especially if traditional healing practices are not respected. Many Navajos are afraid of hospitals because this is where people will die, which is why they avoid it at all costs. ${ }^{18}$

As human care is the main object of interest in nursing, the study recognizes that the measurement of parameters tells us relevant things, but does not tell us everything. Health professionals, as caregivers, provide care, vital, dynamic and unique; it is as if they were looking at the pieces, in some way that we can, magically taking care to reconstruct the totality divided by our "scientific-Cartesian" appearance. ${ }^{19}$

Thus, the work carried out also highlights the need to strengthen collaboration on research on health practices in rural communities and indigenous peoples. This collaboration is particularly urgent in Ibero-American countries, as highlighted in the VIII Ibero-American Congress for Qualitative Research in Health, held in Florianópolis, between Sept tember 4 and 7, 2018. ${ }^{20}$

Concerning the study limitations, they refer particularly to the limited knowledge and development of the Cultural Care Theory in the academic environment of Chile. There are no Chilean studies regarding Leininger's work and ethnonursing. Information on nursing research conducted with the Cultural Care Theory in ethnic groups and ethnonursing is scarce and old. In theses and dissertations related to the themes of nursing care and culture, they often present only the Cultural Care Theory, without referring to ethnonursing, before referring to other qualitative approaches, such as phenomenology. 


\section{CONCLUSION}

The research carried out in Puerto Aguirre (Las Huichas Island) allows supporting and contrasting knowledge related to the form of care used by a community of people who do not live in the continent, and which in particular is far from the few specialized health centers existing in the region. After following the ethnonursing model guidelines, the researcher committed herself to a process of gradual generation of trust and openness to communication with key informants and their families. That way, it was possible to understand their practices, knowledge, beliefs and values related to popular care prevalent in the Mapuche community.

This approach, due to the humility of recognizing that the answers to be reached are unknown and the conviction that they live in the same investigated community, is what allowed us to revalidate the relevance of the Cultural Care Theory as a body of current disciplinary knowledge. Ethnonursing was recognized as the most appropriate methodology to approach a human community and obtain, with participation, the necessary revelations to build solidly supported knowledge.

During the investigation, the researcher found that the general informants of the health team in La Posta did not have a complete knowledge of intercultural health policy as a way to serve the indigenous peoples of Chile. This opens a space for reflection for professionals from the Mapuche community and professionals from La Posta, in order to commit to work, aiming at recognizing the contribution that cultural knowledge can make to fulfill their responsibilities as health service providers and strengthening community and its culture.

Therefore, the full validity of the Cultural Care Theory was acknowledged. Nursing and, in general, the different health professions, tend to complement each other's popular and professional knowledge, learning from each other and thus improving cultural care in the community. The health team's informants expressed a willingness to learn about the ways of caring for the Mapuche community and to develop collaborative work with its members and representatives.

Regarding professional practice and undergraduate training, as stated by Leininger more than sixty years ago, the information collected reinforces once again the urgent need to adapt undergraduate and graduate training. This must be done in order to deliver to nursing professionals the theoretical, methodological and awareness elements related to health and care as cultural phenomena. For a successful performance of ethnonursing, it is essential to enter into dialogue and conversation processes with users/clients/patients and their families. Healing processes require the participation of various actors and due consideration of their values, beliefs, and cultural care practices.

Concluding, research is a valuable contribution of knowledge, which can enrich the practices of health professionals who are confronted in their daily performance with cultural values, beliefs and practices in health. By recognizing them, they will be able to apply their professional knowledge with a holistic view, facilitating intercultural communication and adherence to health treatments in communities.

\section{REFERENCES}

1. Alligood MR. Introducción a las teorías en enfermería: historia, importancia y análisis. En: Alligood MR, Tomey AM. Modelos y Teorías en Enfermería. Barcelona (SP): Elsevier, 2011. p. 3-15.

2. Leininger MM. Transcultural nursing and globalization of health care: importance, focus, and historical aspects. En: Leininger MM, McFarland MR. Transcultural Nursing. Concepts, theories, research and practice. 3rd ed. New York(US): McGraw-Hill, 2002. p. 46.

3. Leininger MM. Life-cycle culturally based care and health patterns of the gadsup of new guinea: a non-western culture. En: Leininger MM, McFarland MR. Transcultural Nursing. Concepts, theories, research and practice. 3rd ed. New York (US): McGraw-Hill; 2002. p. 217-37. 
4. Leininger MM. The Theory of Culture Care and the Ethnonursing Research Method. En Leininger MM, McFarland MR. Transcultural Nursing. Concepts, theories, research and practice. 3rd ed. New York(US): McGraw-Hill; 2002. p. 79-85.

5. Leininger MM. Culture Care Diversity and Universality Theory and Evolution of the Ethnonursing Method. En: Leininger MM, McFarland MR. Culture Care Diversity and Universality: A Worldwide Nursing Theory. 2nd ed. Sudbury, MA(US): Jones \& Bartlett; 2006. p. 29.

6. Instituto Nacional de Estadística (INE). Síntesis de Resultados. Censo 2017. Junio 2018 [cited 2019 Mar 24]. Available from: https://www.censo2017.cl/descargas/home/sintesis-de-resultadoscenso2017.pdf

7. Instituto Nacional de Estadística (INE). Resultados Censo 2017 [cited 2019 Mar 24]. Disponible en : https://resultados.censo2017.cl/Home/Download

8. Leininger MM. Ethnonursing: A Research Method with Enablers to study the Theory of Culture Care. En: Leininger MM. Culture Care Diversity and Universality. 2nd ed. Sudbury, MA(US): Jones \& Bartlett; 2006. p. 43-81.

9. Farrell LS. Culture care of the Potawatomi Native Americans who have experienced family violence. En: Leininger MM. Culture Care Diversity and Universality. 2nd ed. Sudbury, MA(US): Jones \& Bartlett; 2006. p. 207-38.

10. Tym C. Shuar people's healing practices in the Ecuadorian Amazon as a guide to state interculturality: An epistemic case for indigenous institutions [tesis]. Sidney (AU): University of Sydney, Faculty of Arts \& Social Sciences; 2016 [cited 2019 Mar 24]. Available from: https://ses.library.usyd.edu. au/bitstream/2123/17765/1/Thesis_Tym_Shuar\%20People\%27s\%20Healing\%20Practices.pdf

11. Lima RFS, Turrini RNT, Silva LR, Melo LDS, Augusto SI. Práticas populares de cura e o uso de plantas medicinais por mães ribeirinhas no cuidado infantil. Rev Pesq Cuid Fundam [Internet]. 2017 [cited 2019 Mar 20];9(4):1154-63. Available from: https://doi.org/10.9789/2175-5361.2017. v9i4.1154-1163

12. Wenger AFZ. Culture care and health of Russian and Vietnamese Refugee Communities in the United States. En: Leininger MM. Culture Care Diversity and Universality. 2nd ed. Sudbury, MA(US): Jones \& Bartlett; 2006.p. 327-48.

13. Tom-Orme L. Transcultural nursing and health care among native American peoples. En Leininger MM, McFarland MR. Transcultural Nursing. Concepts, theories, research and practice. 3rd ed. New York(US): McGraw-Hill, 2002. p. 435.

14. Mixer SJ, Fornehed ML, Varney J, Lindley LC. Culturally congruent end-of-life care for rural appalachian people and their families. J Hosp Palliat Nurs [Internet]. 2014 [cited 2019 Mar 23];16(8):526-35. Available from: https://doi.10.1097/NJH.0000000000000114

15. Pérez-Huenteo CA. Salud intercultural desde la visión de usuarios y prestadores de salud de las comunas de Cañete y Tirúa [tesis]. Consepción (CL) Universidad de Concepción, Departamento de Psicología-Facultad de Ciencias Sociales; 2015 [cited 2019 Mar 21]; Available from: http:// repositorio.udec.cl/bitstream/11594/2142/3/Tesis_Salud_Intercultural_desde_la_vision_de_ usuarios.pdf

16. Vargas-García S, Berúmen LV, Arias-Pachezo I, Mejía Y, Realivázquez L, Portillo R. Determinantes sociales de la atención comunitaria: percepciones de la enfermera e indígenas Rarámuris. CULCyT [Internet]. 2015 [cited 2019 Mar 22];12(57):310-8. Available from: http://erevistas.uacj.mx/ojs/ index.php/culcyt/article/view/857.

17. Vargas-García S, Berúmen LV, González E, Pizarro N. Cuidado familiar comunitario: percepciones de la enfermera e indígenas Rarámuris. CULCyT [Internet], 2016 [cited 2019 Mar 22];59(13):22635. Available from: http://erevistas.uacj.mx/ojs/index.php/culcyt/article/view/1464. 
18. Donahue EG. Understanding Suicide in the Navajo Population. Proyecto del Programa de Enfermería, Universidad Ashland. 2017 [cited 2019 Mar 20]; Available from: https://etd.ohiolink. edu/!etd.send_file?accession=auashbrook1493839625853056\&disposition=inline

19. Egry EY. ¿Cómo el conocimiento puede impactar en la calificación de la práctica en enfermería y salud?. Texto Contexto Enferm [Internet]. 2017 [cited 2019 Sept 11];26(2): editorial. Available from: http://doi.org/10.1590/0104-07072017002017editorial2

20. Mercado FJ, Gastaldo D, Prado ML. Colaboración Iberoamericana en Investigación Cualitativa en Salud: ¿Colaboración o aislamiento? Texto Contexto Enferm [Internet]. 2018 [cited 2019 Sept 11]; 27(3):editorial. Available from: http://doi.org/10.1590/0104-07072018002018editorial3 


\section{NOTES}

\section{ORIGIN OF THE ARTICLE}

Article extracted from the thesis - Culture care practices used by the Mapuche community and its relationship with professional care, aimed at promoting health in the region of Aysén - Chile, presented to the Post-Graduate Program in Nursing, Universidade Federal de Santa Catarina, in 2019.

\section{CONTRIBUTION OF AUTHORITY}

Study design: Ojeda MAM, Heidemann ITSB.

Data collection: Ojeda MAM, Heidemann ITSB. Villa SEC.

Data analysis and interpretation: Ojeda MAM, Heidemann ITSB. Villa SEC.

Discussion of results: Ojeda MAM, Heidemann ITSB. Villa SEC.

Writing and/or critical review of content: Ojeda MAM, Heidemann ITSB. Villa SEC.

Review and final approval of the final version: Ojeda MAM, Heidemann ITSB. Villa SEC.

\section{FUNDING INFORMATION}

The artifice was financed by the Universidad de Magallanes, with Certificate 89/SU/2017, which contemplates the approval of the sponsorship for the study of the Master in Nursing carried out through Universidade Federal de Santa Catarina, at UMAG, from November 2016 to April 2019. This study was financed by the Coordenação de Aperfeiçoamento de Pessoal de Nível Superior - Brazil (CAPES) - Finance Code 001.

\section{APPROVAL OF ETHICS COMMITTEE IN RESEARCH}

Approved by the Ethics Committee in Research with Human Beings of the the Universidad de Magallanes, Certificate 036/CEC/2018.

\section{CONFLICT OF INTEREST}

There is no conflict of interest.

\section{HISTORICAL}

Received: September 16, 2019.

Approved: February 27, 2020.

\section{CORRESPONDING AUTHOR}

Ivonete Teresinha Schulter Buss Heidemann

ivonete.heidemann@ufsc.br 